\title{
BEING CARED BY A FAMILY MEMBER: THE EXISTENTIAL FEELINGS OF CANCER PATIENTS ${ }^{1}$
}

\author{
Julia Wakiuchi², Anna Maria de Oliveira Salimena³, Catarina Aparecida Sales ${ }^{4}$
}

\footnotetext{
${ }^{1}$ Extracted from the master's dissertation - O cuidado sob o olhar do paciente oncológico: o cotidiano junto à família e a equipe de saúde, presented to the Graduate Nursing Program, Universidade Estadual de Maringá (UEM), 2013. Research financed by the Araucária Foundation for Scientific and Technological Development of Paraná, Brazil.

${ }^{2}$ Doctoral student at the Graduate Nursing Program, UEM. Maringá, Paraná, Brazil. E-mail: julia.wakiuchi@gmail.com

${ }^{3}$ Ph.D. in Nursing. Associate Professor, Undergraduate and Graduate Nursing Program, Universidade Federal de Juiz de Fora. Juiz de Fora, Minas Gerais, Brazil. E-mail: annasalimena@terra.com.br

${ }^{4}$ Ph.D. in Nursing. Professor at the Graduate Nursing Program, UEM. Maringá, Paraná, Brazil. E-mail: casales@uem.br
}

\begin{abstract}
The present article aimed to understand the daily life of cancer patients under palliative care while experiencing home care provided by family members. This was a Heideggerian phenomenological study with 20 patients being treated at the primary health care service of Northeast Paraná, Brazil, between November 2012 and February 2013. Data collection was based on the following research guiding question: What has been your experience of being cared for by your family? Phenomenological analysis was conducted by selecting units of meaning from statements and then selecting ontologic themes, namely: "being alone in the presence of the other" and "finding the foundation of care in love." In conclusion, when based on love and solicitude, home care coupled with palliative practices can give "wings" to those who are suffering and perceive their lives as threatened.
\end{abstract}

DESCRIPTORS: Family. Home nursing. Neoplasms. Palliative care. Nursing.

\section{SENDO CUIDADO POR UM FAMILIAR: SENTIMENTOS EXISTENCIAIS DE PACIENTES ONCOLÓGICOS}

RESUMO: Objetivou-se compreender o cotidiano de pacientes com câncer em cuidados paliativos ao vivenciar o cuidado de sua família no domicílio. This was a Heideggerian phenomological study with 20 patients being treated at the primary health care service of Northeast Paraná, Brazil, between November 2012 and February 2013. Para coleta de dados, utilizou-se a questão norteadora: como tem sido sua experiência ao ser cuidado por sua família? A análise fenomenológica foi realizada pela seleção das unidades de sentido de cada depoimento e posterior seleção das temáticas ontológicas, sendo estas: "permanecendo só ante a presença do outro" e "encontrando no amor o fundamento para o cuidado". Conclui-se que o cuidado domiciliar em consonância com a prática paliativista, quando fundamentado em amor e solicitude, é capaz de dar "asas" àqueles que, no padecimento, visualizaram suas vidas ameaçadas. DESCRITORES: Família. Assistência domiciliar. Neoplasias. Cuidados paliativos Enfermagem.

\section{SER CUIDADO POR UN FAMILIAR: SENTIMIENTOS EXISTENCIALES DE PACIENTES ONCOLÓGICOS}

\begin{abstract}
RESUMEN: Este estudio tuvo como objetivo comprender el cotidiano de pacientes oncológicos en lo cuidado de la familia en domicilio. Estudio fenomenológico de Heidegger en se encuestó a 20 pacientes de la Atención Primaria a la Salud del Noroeste de Paraná, entre noviembre de 2012 a febrero de 2013. Se utilizó la pregunta guía: ¿Cómo ha sido su experiencia al ser cuidado por su familia?. El análisis fenomenológica se realizó mediante la selección de unidades de cada selección y posterior de las cuestiones ontológicas, que son lo que significa: Permaneciendo solo ante la presencia del otro y Encontrando en el amor el fundamento para el cuidado. Se concluye que el cuidado domiciliar en consonancia con la práctica paliativita, cuando fundamentado en amor y solicitud, es capaz de dar 'alas' a aquellos que visualizaron sus vidas amenazadas.
\end{abstract}

DESCRIPTORES: Familia. Asistencia domiciliar. Neoplasias. Cuidados paliativos. Enfermería. 


\section{INTRODUCTION}

The magnitude of cancer, confirmed by its high morbimortality rates, constitutes a public health problem. ${ }^{1}$ Despite technological developments related to diagnostic precision and advanced therapeutic procedures, neoplasms are still grim diseases, requiring long-lasting, painful, and frequently debilitating treatments.

The seriousness involved in the prognosis for cancer is usually linked to fear and negative associations that have a global effect on the patients' spheres of existence, especially on their quality of life after initiating therapy. ${ }^{2}$ Thus, as the experiences involved in the everyday life of individuals with cancer are contextualized, both patients and their family circumstances as a whole have their stability threatened. ${ }^{3}$

Following this line of thought, it is clear the importance of the type of care provided, as cancer must be faced as much more than the physical manifestations caused by the disease, given the relationship between cancer, suffering, and the deterioration of being. This requires comprehension and emotional support from family members in accordance with the patient's care needs. ${ }^{4}$ In order to meet such needs, palliative care should be introduced at the time of cancer diagnosis, ${ }^{5}$ as it allows patients and their family nuclei to actively participate in the therapeutic process and act as a team when faced with treatment options and care-related decisions. ${ }^{6}$

However, while receiving home care, patients experience an assortment of feelings that emerge from the patient-caregiver relationship in the context of the daily care routine. The literature has shown that recognizing the diligence and attention provided by family members, counteracts feelings of dependency and obligation felt by chronic patients, in addition to any predicaments that can occur during the care process. ${ }^{7}$

In the meantime, the everyday life of caregivers and care receivers is marked by an extremely close relationship, which can both strengthen the bonds and reciprocity between them and unleash conflicts and disagreements that will be expressed through the most diverse emotions within this pair. ${ }^{8}$ Considering that cancer patients experience both their own emotions related to the process of illness and treatment and the distinctive impressions and anxieties that permeate their care, we asked: How do cancer patients feel when receiving home care by their family?
In the Brazilian literature, there is still a lack of studies that address home care for cancer patients. ${ }^{9}$ Such a gap becomes even more evident when touching on the subject of patients' feelings and perceptions about home care. Thus, it is important to understand the feelings experienced by patients during the process of home care, as the transformations in their lives caused by cancer require attention and care.

With this study, we hoped to have underpinned the importance of the family in home care for oncology patients. Our objective was to sensitize health professionals to the magnitude of such situations and the need for them to constantly increase their knowledge and skills. In so doing, they can provide support in a time in people's lives usually permeated by doubt and difficulty. Thus, the aim of the present article was to understand the daily life of cancer patients under palliative care while experiencing home care provided by family members.

\section{METHODOLOGY}

This was a qualitative study based on existential phenomenology. ${ }^{10}$ This approach allowed us to focus on the phenomenon in order to understand others in their facticity, considering individuals within their singularities; in other words, as people in their own existential totality. ${ }^{10}$

The subjects of this study were cancer patients under palliative care under the scope of the Family Health Strategy program (FHS) in a city in the Northeast of the state of Paraná, Brazil. We selected basic health units (BHUs) from the Brazilian National Registry of Health Facilities, and those with the greatest number of FHS teams were chosen for this study. Three BHUs were included, one with four FHS teams and two with five FHS teams. We conducted a survey of all the cancer patients in these FHSs in November 2012 with the help of the FHS teams, community health agents (CHA), and the nurses responsible for each area.

Inclusion criteria for the study were: being 18 years or older; residing in one of the areas within the scope of the FHS of Maringá, state of Paraná, Brazil; and having received cancer treatment for over six months. The last criterion aimed to select patients who had already been cared for by the healthcare teams after the onset of cancer and who could express this experience in their 
speech. Furthermore, patients had to be in physical and mental conditions to answer questions, a criterion that was assessed together with the FSH teams while selecting participants. Hence, we excluded patients who were tracheotomized and could not respond to the interview orally and patients diagnosed with neurodegenerative diseases or mental disorders as specified in the FHS records, as such pathologies could interfere when trying to answer questions based on their actual experience.

After identifying the subjects, we scheduled our first visits together with the CHAs, in order to take advantage of the already-existing bond between them and the patients and to comply with the ethical precepts of anonymity and confidentiality. ${ }^{11}$ The other meetings were scheduled without the presence of the CHAs and led to empathetic moments in which feelings were shared. Each patient was visited and interviewed approximately three times between November 2012 and February 2013.

The researcher used the interrogation method in order to gain closer access to the discourse of the individual experiencing the analyzed situation. In so doing, the interviewer started down a path towards the phenomenon, or what manifests itself. $^{12}$ To this end, the guiding question of the study was: What has been your experience of being cared for by your family? We also collected sociodemographic data and information on the disease and treatment received.

The audio of the interviews was recorded in its entirety; the behaviors of the interviewees, such as pauses, moments of silence, tears, expressions, smiles, and touching were recorded in the field diary so that they could be analyzed together with the speech. The same researcher that conducted the interviews was responsible for their transcription. This was done in order to transmit the greatest possible reliability through the languages used by participants.

Data analysis was based on Heidegger's existential phenomenology, which starts with the ontic and moves toward the ontologic, thus discovering the phenomenon that is unconcealed to the researcher. Therefore, first, we carefully read the interviews in order to separate meaningful excerpts or units that appeared as fundamental structures of the participants' existence. In other words, we selected excerpts that included the feelings expressed by the interviewees during an ontologic interrogation. ${ }^{13} \mathrm{Next}$, we analyzed these units of meaning to conduct the phenomenological selection of each one, giving rise to ontologic themes. ${ }^{13}$ These themes were analyzed in light of some ideas from Heidegger's analytic philosophy, postulates of palliative care, and authors who deal with this field of study.

The anonymity of patients was ensured by using pseudonyms from the book "The Diary of Anne Frank". This book is the true story of a 12-year-old Jewish girl written in the form of a diary while she was in hiding with her family and friends during the Nazi persecution of the Jews. ${ }^{14}$ Her writings are pertinent to cancer patients, as they originated from a daily life lived in isolation, anguish, sacrifice, and fear, in which her diary was her only confidant.

This study abided by the regulatory standards and norms for human research as established in Resolution 196 of October 10, 1996, later substituted by Resolution 466, of December 12, 2012,11 of the Brazilian National Health Council. To this end, subjects were given Informed Consent Forms, which they signed in duplicate. Furthermore, as the current research is affiliated with the project called "The applicability of palliative care in basic health care, promoting improved quality of life for patients with malignant neoplasm, their families, and health professions", it was also approved by the Permanent Committee of Human Research Ethics of the Universidade Estadual de Maringá, under protocol no. 435/2011.

\section{RESULTS AND DISCUSSION}

Twenty home care cancer patients were included in the results of this study. Of these, 7 were men and 13 were women, all between the ages of 35 and 77 . Ten received care from their spouses, four were cared for by their offspring, two by their mothers, two by their sisters, one by a sister-inlaw, and one by an aunt. Cancers were located in the brain, neck, larynx, breasts, lungs, intestines, uterus, prostate, and one was leukemia; of these, five presented metastases. Time of diagnosis ranged from seven months to eight years and all patients were receiving antineoplastic treatment at the time of the interview, i.e., chemotherapy, radiotherapy, or postoperative recovery.

Language analysis revealed a mixture of feelings expressed by the patients, which ranged from the desire of being cared for to gratitude for the attention provided by family members. 


\section{Being alone in the presence of the other}

According to Heidegger's analytics, our encounter with others is guided by our own beingin-the-world. In daily coexistence, we are placed before others who, far from representing those different fom us, are among those from whom, for the most part, we cannot distinguish ourselves. As such, the human being is also living amid others in the shared world of this encounter. ${ }^{10}$

In this perspective, encounters with the other take place in the world in which the being-there is not only concerned with the other, but mostly occupied with intra-mundane beings. Thus, "the being-with existentially determines presence, even when the other is not in fact given or perceived. Even the being-alone of presence is a form of being-with in the world. The other can be lacking only in and for a being-with. Being-alone is a deficient mode of being-with; its possibility is a proof for the latter". ${ }^{10: 177}$

In light of these considerations and under the prism of co-existence, those who provide care frequently deprive themselves of understanding their pre-ontologic constitution and are involved in an unauthentic form of being, hiding in the impersonal in which they usually remain..$^{15}$ Thus, frequently, it is in such an unauthentic mode that human beings provide care, maintaining a certain distance from the care receiver. Therefore, in this case, caregivers are together-with, but are not open to being-with-one-another, as demonstrated in the speech below.

[...] Just last week I spent three days in which I only got up to try to eat something, and even my daughter, on the days I have chemo, when I'm doing worse, she doesn't come to help [...]. Those who see you can't know what you're feeling, so you don't know what suffering a person is experiencing. Nobody knows. Sometimes I go to my mother's house and chat with her, like I'm doing here with you, and they think having cancer is easy, that it's simple (Anne); [...]. I think that instead of pressuring me, saying that I should eat, that I have to gather up my strength, they should stay here with me, because it's the only way they can take care of me (Henk); My sister-in-law, my sister, they call me, but they don't come here to give me support. I think the family has to be there, it's important. So, because of such things, I used to be sad in the beginning, but not anymore. I believe that such things can even make you stronger, because then you know who you can count on (Wessel).
On analyzing the participants' discourse, they reported experiencing a certain "affective detachment" from their own families. In other words, their family members were close to them, but distant at the same time, as they didn't effectively take part in their pain. The desire to know how the other is feeling was limited to a superficial perception, which escaped from true openness to the unveiling of what was actually being experienced at that moment. For these individuals, palliative care is but an ideal, as this philosophy seeks to provide individuals with the greatest possible care at home through the support of their families. ${ }^{16}$

By transposing this reality to Heidegger's analytics, we understand that, because relationships with the other were based on modes of indifference and/or deficiency, patients felt excluded, as others did not reach them. These attitudes, which are characteristic of average and everyday co-existence, are due to feelings of uncanniness before the mishaps of the other. ${ }^{15}$

Inasmuch, the being-in-the-world can be alone even when the other or several others are co-present, as these frequently come to their encounter in modes of indifference or uncanniness. The latter is understood as the feeling of not being at home, and it is the most primordial phenomenon, ${ }^{10}$ existentially and ontologically. Not recognizing things as they are is a feeling of those who do not belong anywhere. The public nature of the impersonal represses all nonfamiliarity, and being together-with, whether understood or not, is veiled, as if the subject were fleeing from understanding. ${ }^{10}$ By avoiding what is unpleasant, family members exhaust their possibilities of being-with the patient authentically.

The lack of emotional reaction of the other before such lack of devotion and care for the patient show us that even in face of the difficulties of cancer treatment, those who experience the illness remain the foundation of support in their homes. By transcending the barriers imposed by the disease, patients find the possibility of caring for the other when they themselves need care, as portrayed in the following excerpts.

[...] I went after everything myself. Since I have always been the soul of this house, my husband was helpless, he didn't take any action, he was lost. So I went, I thought: 'I have to go!' I had my hair cut, because I knew they were going to shave it off. Before going into surgery, I did all the Christmas shopping 
so that they would want for nothing. I tidied up the house, the room, so that afterwards I would have clean linen and everything. And up to this day I'm the one who takes the lead, that's the way it is. (Anne); [...] I didn't receive 'care'; nobody took the initiative of helping me. So I have always took care of things myself! I dealt with everything while taking care of myself and the others, who can't live without me. Of course, there are times when it's impossible; you have to ask for help. However, each person deals with it in their own way, there are those who become dependent, there are those who put on a strong facade, [there are those] who exaggerate. I have always been like this, alone. (Elli); [...] God is the one taking care of me! [laughter]. It's God! Because, to tell the truth, it's not easy [she reflects for a moment and her eyes tear up]. But I am a fighter, you know, I am a strong woman! For me to lose my spirits, it has to be something big [laughter]. I feel that I am the pillar here at home, because if I lose heart, then... (Edith).

The participants had experienced in their journey a time in which they could take care of both themselves and others on their own, but at the time of the interview, they had the need to receive care, which was not available at home. This was expressed in the participants' discourse, which revealed that while they coexisted with the facticity of being the mother responsible for the home and coping with the process of illness and their frailties at the same time, they wished to move from "being-caredwith" to "being cared for."

In the language used by Edith, we noticed that when she perceived herself as unsupported in her fight against cancer, she directed her source of relief and consolation to an intangible plane and turned to the presence of a Supreme Being for comfort. The multidimensional complexity of spirituality makes it a vital element for many patients under palliative care. Its purpose can range from a form of emotional support to a search for meaning, purpose and transcendence in life. ${ }^{17}$

Based on this analysis, the onset of a disease like cancer, which brings deep changes to the lives of those who live with it, caused in the participants an avalanche of feelings, sometimes related to the search for support, sometimes questioning the authenticity of those who offered a hand. However, transiting in impropriety is not a static process, but a journey in search of authenticity that, within the home, can reach pure palliativism as a form of care, as shown in the next category.

\section{Finding the foundation of care in love}

Family care is a multidimensional phenomenon, simultaneously visible and abstract. It involves feelings of affection, harmony, and the necessary responsibility for such a stance. ${ }^{7}$ The principles of palliative state that the home environment is the best place for patients to enjoy the humanized aspects of care. In their own home, they can organize a more individualized and informal routine capable of providing comfort and quality of life. ${ }^{9}$

Heidegger conceives care as an ontologic condition that makes existence possible, and as such, is inherent to man in his mode of living. ${ }^{4}$ When governed by care, a relationship with the other depends on interpellation, i.e., being-there as care can only be open if the other is allowed to unconceal himself and manifest his anguish authentically or inauthentically in different moments of his life. ${ }^{18}$

Amid all the chores, relationships, and obligations of each Dasein, the modes of occupation and preoccupation, or solicitude, are in full force. These manifest themselves in the unfolding in which care is formed in average everyday life. ${ }^{19}$ Authentic care can be manifested through solicitude, which in its own way seeks to anticipate the other in a considerate stance, taking on the responsibility for his care. ${ }^{10}$ Solicit care paves the way so that the other can take responsibility for him or herself. In other words, authentic care opens up possibilities for being one's own self. ${ }^{20}$

Caring for a family member with cancer through authentic solicit manifestations allows caregivers to enter the patient's existential dimension and become a being-with-the-other. ${ }^{21}$ Beingwith determines that "the I never has to leave itself to enter the world of the other", ${ }^{20: 168}$ as it communicates in the shared world of coexistence in an ontologic and existential manner, in which he is already and has always been available to the other.

From the moment the family recognizes itself as the center of caregiving and takes full responsibility for this task, it begins a process of positive influence regarding the coping strategy used by the patient, decision making, daily self-care tasks and displays of affection. ${ }^{22}$ Even though patients did not clearly express such feelings of gratitude to the other, they recognized their importance and held them in esteem. Margot's discourse is an example of acknowledgement of the immensity of care received. 
[...] I received total support from my family. My aunt, nieces and nephews, and siblings all took turns, everybody called and visited me. Even my sisters-inlaw, which I like so much. So I always felt taken care of. I was happy to see that my family was always by my side, supporting me (Jopie); [...] I found my sisters to be a great source of support. They help me so much! They are so patient! [When her sister enters the room, she gives a coy smile and interrupts her praise]. I think that the fright I gave her made her blood pressure rise and she is already of a certain age. [She is silent for a bit, until her sister leaves] But she has been with me from the beginning, she talks with the doctors, she knew what was happening, both in terms of the disease and the suffering I experienced. Without her, I don't know... (Margot); My wife does everything for me: food, bath, she tries to please me and every thing. Poor thing. She does what she can. I think she helps me too much! Because since I've been this way, I've changed a lot, I don't do anything anymore! But she still helps me; she gives me everything I need (Vossen).

These statements show that the unconditional support of the family nurtured the patients' health and wellbeing, reflected in their recognition of the efforts of the other to care for them. For these patients, the care received surpassed expectations and there were no gaps in care. Considering that a family fabric was woven for provision of care, patients did not report moments of loneliness or suffering. Furthermore, they referred to the period of treatment as a time of union, sharing, and love. Family members must take the lead in overcoming the obstacles presented by cancer by acting as the pillar of psychological support, in addition to reorganizing the entire home dynamic in order to adapt to the new conditions imposed by the disease. ${ }^{23}$

From this perspective, the devotion of these family members to the patient agrees with the concept of dedication, through which the human being emerges as a presence in his own existence and penetrates into the possibility of things, leading one to a primordial comprehension of such things. ${ }^{20}$ In dedication mode, one gives of one's self to the world without losing the power-to-be-oneself. Furthermore, individuals expose themselves through this positive care, which builds them up authentically by means of surrender and diligent and affectionate creation. ${ }^{20}$

The participants' discourses also portray a co-existence marked by affection, in which a person that takes on the care for another transforms his or her life into surrender to unconcealment.
Such full dedication to the other, by means of minimal gestures, seems to decrease the burden of cancer and the suffering associated with it, as this burden ends up being shared between caregiver and care receiver.

My wife does everything for me, everything, because I can't do a thing. I even feel sorry for her. Even when I put a shirt on, she has to go and get it for me and help me put it on. I can't do anything; she's with me all the time. Here at home I have everything, everything I need, I have (Hans); My sister-in-law stopped living her life. She had already interrupted it to live with my father for three months and two months later, she left her life to come live mine, together with me. She goes everywhere with me, to the doctor, tests, chemo, home. She only goes home once I've eaten, when she thinks I am ok. And before you know it, she's back here again [laughter] (Miep); My mother-in-law gave me a lot of support, you know, she comes to my house every day, she supports me in every sense, I think it's abuse [laughter]. She helps me with work, she helps me with family problems, and with this support, everything is easier (Petronella).

Such bonds between patient and caregiver emanate feelings of extreme joy and gratitude, reflected in the facial expressions of participants when they referred to the person who cared for them. In consonance with the patients' statements, we noticed that the care received was capable of transcending the anguish brought on by cancer and made it so that this time in their lives could manifest itself as the revelation of an unconditional being-with.

This mode of care, in its own particular way, reaches the meaning of its act ontologically and understands what is authentically important in the other. Primordially, providing care is the act of truly taking on the possibilities of being and, to this end, allowing to be guided by it and becoming attached; it is a loving attachment. ${ }^{20}$

Care involves directing both emotional and expressive feelings to the other, and such feelings must focus on developing the caregiver's awareness and valuing the individuality of care receivers. ${ }^{7}$ Undoubtedly, family is the most ancient and the strongest institution of care, rooted in a system of socialization and interaction in which the limitation of a member of its bonds not only concerns the whole unit, but also leads them to redirect one of their own to the care of the other. ${ }^{24}$

Thus, despite the cultural heritage that flaunts women as primordial caregivers, we found 
that both men and women had provided care to the interviewed patients. In the case of spouses, these remained faithful to their loved ones and the care provided gave new life to the affection between the couple.

When we get married there's that thing that says: in health and in sickness, in richness and in poor. Look, she has been victorious in this phase; I don't know if I could have taken what she has been dealing with. She is everything to me. But if you don't have a partner, you end up dying. I am rich in partner. Not in children, they hang around for an hour, and then they forget. But my partner! And you get so attached after this, it changes everything in life, it changes all the freedom of love, of knowing who is by your side, wow! There's nothing like it (Harry); [...] my husband is a boyfriend to me, a father, my everything. The hair in his head is a bit white, but he's my boyfriend! After I got sick, he even wants to cook for me, he makes different kinds of pies; he makes up recipes to make me happy. He looks them up on the Internet and then makes them. I'll tell you the truth, with everything he does for me, it's like I don't even have this disease! I feel so exalted! (Sanne).

These statements show how the relationship between man and wife was renewed. The difficulties of living with cancer mobilized feelings, and these feelings were reflected in kindness, affection, and giving of oneself to the other. Moreover, the palliative approach advocates that in order to improve the quality of life of those receiving care, support must be provided primordially through love in the home. ${ }^{2}$

The possibility of a relationship is the basis of care. When care is interwoven with love, affection, and benevolence, the being-with can form relationships and begin down the path towards the desire to take on this function. ${ }^{20}$ When care is a consequence of love, it happens naturally. Thus, the attitudes and feelings present in the process of devotion and attention originate from actual desire, making them truly authentic.

The discourse of patients who received authentic care from their families expressed the impact that this attitude had on the course of their disease and their lives. Before the difficulties brought on by cancer, they found an opportunity to grow and transcend through care. Their lives gained new meaning coupled to feelings of acknowledgment and gratitude for the attitudes of those who offered care.

The current research was limited to the population cared for by the Family Health Teams of a municipality known as a reference center for cancer treatment, and therefore, we recognize that our results do not encompass the reality and feelings experienced by all families living with cancer. Due to the particularities of this situation, each family should be analyzed within the context of their care facility. We were not able to include patients who lived in regions not covered by the FHS, even within the municipality in question, as such experiences can be distinctive. Also, these situations should serve as a reference to indicate the need for these places to be included in care coverage.

\section{CONCLUSIONS}

Heidegger's hermeneutic and analytic movement allowed us to unveil the paths undertaken by care installed in the homes of cancer patients under palliative care. In the beginning of our journey to understand these patients, we found an inauthentic being-with, in which relationships were concealed by distance and self-accommodation. Many remain in this state of uncanniness, and in so doing, avoid paving the way to authenticity.

However, before the horizon of possibilities into which man has been thrown, the encounter of solicitude also manifests itself through responsible and individualized attitudes that transform care into an expression of devotion and love. Such circumstances indicated that authentic care is connected to the legitimate desire of executing this function, which is confused with the feelings that one has for the care receiver. In this situation, receiving care becomes the factor that solidifies relationships and the love between caregivers and care receivers.

This study showed the magnitude of home care that, in consonance with palliative care, can give "wings" to those who experience suffering and experience a threat to their life. When based on love and solicitude, home care can transform the period of the disease into a time of recognizing oneself and manifesting the best feelings of being alive. Through an act in which one surrenders to another, the burden of the disease can be shared and joy can emerge.

It is essential for nursing to value this instance of care, for without the support and information of healthcare teams, living with the disease and its difficulties can become an abstract experience, which does not always contemplate all 
the health and personal needs of an individual. We emphasize the value of the discourse in this study, which indicates the need for patients and families to be oriented so that they can alleviate the reality of cancer and so that healthcare teams, patients, and families can work together. Healthcare teams are also responsible for helping families find stability in home care, a factor that requires proximity with families and with the reality experienced by patients. Active listening, open dialogue, and humanized attitudes align nursing care with the wishes and needs of the patient, as portrayed in this study.

It is important to emphasize that as this study was conducted in a city that is a reference for cancer treatment in its region, and whose healthcare teams have their own particular culture and behaviors, this study was restricted to depicting a reality which might not reflect or be applicable to other contexts. Thus, we emphasize that further studies are needed in this area to clarify possible deficiencies in health care for cancer patients and find strategies that can establish a new level of care in oncology nursing.

\section{REFERENCES}

1. Gomes NS, Silva SR. Avaliação da autoestima de mulheres submetidas à cirurgia oncológica mamária. Texto Contexto Enferm [online]. 2013 [acesso 2014 Dez 01]; 22(2):509-16. Disponível em: http:/ / www.scielo.br/scielo.php?pid=S010407072013000200029\&script $=$ sci_arttext

2. Fabricka P, Nowick A. Selected aspects of palliative care and quality of life at the terminal stage of neoplasic disease. Contemp Oncol (Pozn). 2012 Jan; 16(6):506-11.

3. Fernandes AF, Bonfim IM, Araújo IMA, Silva RM, Barbosa ICFJ, Santos MCL. Significado do cuidado domiciliar à mulher mastectomizada. Esc Anna Nery. 2012 Jan-Mar; 16(1):27-33.

4. Sena ELS, Reis HFT, Carvalho PAL, Souza VS. A intersubjetividade e o conhecimento na perspectiva fenomenológica. Rev Rene. 2011 Jan-Mar; 12(1):181-8.

5. Capello EMCS, Velosa MVM, Salotti SR, Guimarães HCQP. Enfrentamento do paciente oncológico e do familiar/cuidador frente à terminalidade da vida. J Health Sci Inst. 2012; 30(3):235-40.

6. Kirk RA, Brawley O. Palliative care: a lifeline to quality of life. J Oncol Pract. 2012 Mar; 8(2):128-9.

7. Faber V, Rosanelli CP, Loro MM, Kolankiewicz ACB, Piovesan S, Leite MT. Percepções de doentes crônicos acerca do cuidado prestado por familiares. Ciênc Cuid Saude. 2012 Jul-Set; 11(3):565-72.
8. Baptista BO, Beuter M, Girardon-Perlini NMO, Brondani CM, Budó MLD, Santos NO. A sobrecarga do familiar cuidador no âmbito domiciliar: uma revisão integrativa da literatura. Rev Gaúcha Enferm. 2012 Mar; 33(1):147-56.

9. Oliveira SG, Quintana AM, Budó MLD, Lüdtke MF, Cassel PA, Wottrich SH. Familiares cuidadores e a terminalidade: tendência da produção científica na área de saúde. Rev Min Enferm. 2011 Out-Dez; 15(4):588-94.

10. Heidegger M. Ser e tempo. Petrópolis (RJ): Vozes; 2012.

11. Ministério da Saúde (BR). Conselho Nacional de Saúde. Resolução n ${ }^{\circ}$ 466, de 12 de dezembro de 2012. Aprova as diretrizes e normas regulamentadoras de pesquisas envolvendo seres humanos. Diário Oficial da União, Brasília, 13 jun. 2013.

12. Sales CA, Silva VA, Pilger C, Marcon SS. Música na terminalidade humana: concepções dos familiares. Rev Esc Enferm USP. 2011 Mar; 45 (1): 138-45.

13. Josgrilberg RS. A fenomenologia como novo paradigma de uma ciência do existir. In: Porladeck DD. A fenomenologia do cuidar: prática dos horizontes vividos nas áreas da saúde, educacional e organizacional. São Paulo (SP): Vetor; 2004. p. 31-52.

14. Frank OH, Pressler M. O diário de Anne Frank. Rio de Janeiro (RJ): Record; 2013.

15. Martins Filho JRF. Heidegger e a concepção de "outro" em ser e tempo. Aproximação. 2010 JanJun; 3:56-76.

16. Ferris FD, Bruera E, Cherny N, Cummings C, Currow D, Dudgeon D, et al. Palliative cancer care a decade later: accomplishments, the need, next steps. J Clin Oncol. 2009; 27(18):3052-58.

17. Asgeirsdottir GH, Sigurbjörnsson E, Traustadottir R, Sigurdardottir V, Gunnarsdottir S, Kelly E. “To cherish each day as it comes": a qualitative study of spirituality among persons receiving pallitive care. Support Care Cancer. 2013; 21:1445-51.

18. Oliveira MFV, Carraro TE. Cuidado em Heidegger: uma possibilidade ontológica para enfermagem. Rev Bras Enferm. 2011; 64(2):376-80.

19. Nogueira RP. Extensão fenomenológica dos conceitos de saúde e enfermidade em Heidegger. Cienc Saúde Colet. 2011; 16(1):259-66.

20. Fernandes MA. Ocuidado como amor em Heidegger. Rev Abordagem Gestalt. 2011 Jul-Dez; 17(2):158-71.

21. Sales CA, Matos PCB, Mendonça DPR, Marcon SS. Cuidar de um familiar com câncer: o impacto no cotidiano de vida do cuidador. Rev Eletr Enferm [online]. 2010 [acesso $2014 \mathrm{Dez}$ 01]; 12(4):616-21. Disponível em: http://www.fen.ufg.br/revista/ v12/n4/pdf/v12n4a04.pdf

22. Ferreira AMC. Amor e liberdade em Heidegger. Kriterion. 2011; (123):139-58. 
23. Violim MR, Bringmann PB, Marcon SS, Waidman MAP, Sales CA. O significado de conviver com um familiar com estomia por câncer gastrointestinal. Rev Rene. 2011 Jul-Set; 12(3):510-7.
24. Rodriguez LH. Los qué, cuándo, por qué y como de la sedación paliativa. Rev Hosp Ital B Aires. 2010 Dez; 30(2):69-76. 